\title{
Likya Yolu Yürüyüşçülerinin Profilleri ve Memnuniyet Düzeyleri
}

Profiles and Satisfaction Levels of Lycian Way Walkers

\author{
Burcu TÜTÜNCÜ*, Hüseyin PAMUKÇU**, Canan TANRISEVER*** \\ * (Sorumlu Yazar), Bilim Uzmanı, Kastamonu Üniversitesi, Turizm Fakültesi, Turizm İşletmeciliği Bölümü, Kuzeykent, Orgeneral Atilla Ateş Paşa Caddesi. No: 15/A, \\ 37150, Sarıömer, Kastamonu. \\ E-posta: burcututuncu95@gmail.com \\ ORCID: 0000-0003-1870-8042 \\ **Dr. Öğr. Üyesi, Kastamonu Üniversitesi, Turizm Fakültesi, Turizm İşletmeciliği Bölümü, Kuzeykent, Orgeneral Atilla Ateş Paşa Caddesi. No: 15/A, 37150, \\ Sarı̈mer, Kastamonu. \\ E-posta: pamukcuhuseyin@gmail.com \\ ORCID:0000-0002-9673-5604 \\ ***Doç. Dr., Kastamonu Üniversitesi, Turizm Fakültesi, Turizm İşletmeciliği Bölümü, Kuzeykent, Orgeneral Atilla Ateş Paşa Caddesi. No: 15/A, 37150, \\ Sarı̈̈mer, Kastamonu. \\ E-posta: ctanrisever@kastamonu.edu.tr \\ ORCID: 0000-0003-4747-5903
}

MAKALE BILGILERI

Makale işlem bilgileri:

Gönderilme tarihi: 1 Kasım 2019

Düzeltme: 14 Ocak 2020

Düzeltme: 3 Şubat 2020

Düzeltme: 4 Mart 2020

Kabul: 7 Nisan 2020

Anahtar sözcükler: Turist memnuniyeti, Kültür rotası, Likya Yolu.

\section{ARTICLE INFO}

Article history:

Submitted: 1 November 2019

Resubmitted: 14 January 2020

Resubmitted: 3 February 2020

Resubmitted: 4 March 2020

Accepted: 7 April 2020

Key words: Tourist satisfactions, Cultural route, Lycian Way.

\begin{abstract}
ÖZ
Likya Yolu Rotası, Türkiye'nin işaretlenen ilk kültür rotasıdır. Sahip olduğu doğal, kültürel ve tarihi değerleriyle ön plana çıkan rotayı ziyaret eden turist sayısı gün geçtikçe artıș göstermektedir. Çalıșmanın temel amacı Likya Yolu yürüyüşçülerinin, yürümüş oldukları etapların olanaklarına yönelik memnuniyet düzeyinin belirlenmesidir. Katılımcıların demografik özelliklerinin belirlenerek, yürüyüşçü profilinin saptanması ise çalışmanın bir diğer amacını oluşturmaktadır. Nicel açıdan betimsel araștırma modelinden faydalanılan araștırmada, kolayda örnekleme yöntemi ile 416 yürüyüşçüye ulaşıımıştır. Çalışmanın verileri anketler aracılığıyla elde edilmiştir. Anketler katılımcılara 2018 yılının Eylül, Ekim ve Kasım aylarında uygulanmıştır. Elde edilen veriler sonucunda yürüyüșçülerin büyük bir kısmının 40 yaș ve üzeri, bekâr ve en az lisans düzeyinde eğitim seviyesine sahip olduğu ortaya konulmuştur. Memnuniyet düzeyine yönelik yapılan analizlerle, katılımcıların rotanın güvenliğine dair memnuniyetlerinin yüksek düzeyde olduğu, ancak su kaynağı kısıtıılığı, çevre kirliliği, bilgilendirici ve yönlendirici levha eksikliği gibi birçok unsurun memnuniyeti olumsuz etkilediği sonucuna ulaşılmıştır. Çalışmada elde edilen bulgulardan hareketle birtakım öneriler geliștirilmiştir.
\end{abstract}

\begin{abstract}
Lycian Way is the first cultural route of Turkey. The number of tourists visiting the route which stands out with its natural, cultural and historical values, is increasing day by day. The aim of this study is to determine the satisfaction levels of the Lycian Way about the facilities of their walking paths. The other aim of it is to determine the walkers' profile by detecting demographic features of the participants. In the research which descriptive research model was used quantitatively, 416 participants were reached by being used simple sampling method. The data of the study were obtained through the questionnaires. The questionnaires were implemented to participants in September, October and November 2018. As a result of the data obtained, it was revealed that most of the walkers were single, over $\mathbf{4 0}$ years old and had at least undergraduate level. According to the analysis about satisfaction level, it has been concluded that participants' satisfaction level about route safety is high, but several factors such as lack of water source, environmental pollution, lack of informative and directive signboards affect the satisfaction negatively. Some suggestions have been brought forward with reference to the data obtained in this study.
\end{abstract}

\section{GiRiş}

Son yıllarda önemi giderek artan kültür rotaları ilk kez 1964 yılında Avrupa Konseyi çalışma grubu tarafından ortaya atılmıştır (Karataş 2015: 14).
Bu rotalar, turistleri bir bölgeye çekmenin yanı sıra onları zaman ve para harcamaya teşvik etme potansiyeline sahip olmayan çeşitli cazibe merkezlerini birbirine bağlamaktadır (Meyer 2004: 
2). Kültür rotası fikri, seyahat aracılığıyla Avrupa kültürüne yönelik farkındalık oluşturmak, kültürel turizm için ağlar yaratmak ve Avrupa kültürel mirasını sosyal bir teşvik aracı olarak kullanma temeline dayanmaktadır (Briedenhann ve Wickens 2004: 72). Kültürel rotalar, farklı coğrafik unsurlar barındırması, farklı seyahat araçları kullanılabilmesi ve günümüze ya da tarihin belli bir dönemine ait unsurları birleştirebilmesi sebebiyle çeşitlilik göstermektedir (Puczkó ve Rátz 2006: 133).

Likya Yolu Rotası, Türkiye'de işaretlenen ilk kültür rotasıdır (Kulözü 2009; Clow 2017). Kate Clow tarafından oluşturulan proje, 1996 yılında Garanti Bankası öncülüğünde gerçekleşen kültür ve sanata destek projeleri yarışmasını kazanması sonucu Türkiye'ye kazandırılmıştır. Kate Clow ve gönüllülerle birlikle gerçekleştirilen işaretleme ve haritalandirmayla birlikte 1999 yılında rota tamamen açılmıştır (Turgut ve Clow 2010; Pazarbaşı 2014). Özel ilgi turizmi çeşitlerinden olan bu rotanın olanaklarının iyileştirilmesi, geliştirilmesi ve daha fazla ziyaret edilebilmesi için yürüyüşçülerin istek ve ihtiyaçlarının belirlenmesi adına profillerinin ortaya konulması ve memnuniyet düzeylerinin belirlenmesi gerekmektedir (Demirkol, Salha ve Cinnioğlu 2016: 1). Bu doğrultuda çalışmada Likya Yolu Rotası'nı yürüyen turistlerin profillerinin ve rota ile yakın çevresinin sahip olduğu olanaklara yönelik memnuniyet düzeyinin belirlenmesi esas alınmıştır.

\section{TURIST MEMNUNIYETI}

Küreselleşme, uluslararası rekabetin artışı, eğitim düzeyinin yükselmesi ve turizm bilincinin artmasıyla beklenti ve isteklerde değişim meydana gelmiş ve müşteri bilinci kavramı oluşmaya başlamış, müşteri memnuniyetine ilişkin çalışmalara yoğunluk verilmeye başlanmıştır (Özgen 2000; Kılıç ve Pelit 2004). Parasuraman, Zeithaml ve Berry (1994), memnuniyetin sağlanmasında hizmet kalitesi unsurlarının (nezaket, duyarlılık, vb.) yanı sıra satın alınacak ürünün niteliklerinin de (otel odası büyüklüğü, vb.) önemli olacağını öne sürmektedir (Cam 2011: 9). Turist memnuniyeti de turistlere sunulan bu mal ya da hizmetin beklentiyi karşılaması sonucu genel memnuniye- tin ve aynı ürün ya da hizmetten tekrar yararlanma isteğinin oluşmasıdır (Pizam, Neumann ve Reichel 1978; Buluk 2016).

\section{ILGILI ÇALIŞMALAR}

Sahip olduğu doğal ve kültürel unsurlarıyla ön plana çıkan Likya Yolu, Türkiye için oldukça önemli bir fırsattır. Rotanın sahip olduğu olanakların en etkin ve verimli şekilde değerlendirilebilmesi için gelen turistlere yönelik Likya Yolu memnuniyet düzeylerinin belirlenmesi önem arz etmektedir. Likya Yolu Rotası yirmi yıldır yürünse de kültür rotalarının bilinirliği son yıllarda artmıştır. Ancak alanyazında Likya Yolu ile ilgili k1sıtlı çalışma bulunmaktadır.

Likya Yolu ile ilgili yapılan ilk çalışma Baştemur'un 2011 yılında Likya Yolu ve çevresinde yer alan doğal ve kültürel kaynakların belirlenerek, Avrupa Kültür Rotaları programına dâhil edilmesini sağlamak adına yapılabileceklerin ortaya konulmasını amaçlayan çalışmasıdır. Pazarbaşı ise 2014 yılında Likya Yolu Rotası'nın altı etabında ziyaretçilerin demografik özellikleri, seyahat motivasyonları, memnuniyet düzeyleri ve geleceğe yönelik davranışlarını incelemiştir. Likya bölgesini ziyaret eden turistlerin gastronomi kültürüne yönelik tutumları, yiyecek içeceklerle ve işletmeler ile işletme çalışanları hakkındaki görüşlerini irdelemek üzere de Üzümcü, 2018 y1lında bir çalı̧̧ma yapmıştır.

Likya Yolu yürüyüşçülerinin memnuniyet düzeylerinin kapsamlı bir şekilde belirlenmesinin hedeflendiği bu çalışmada rota üzerinde yer alan destinasyonların eksik yönleri ortaya konulmaya çalışılmıştır. Çalışma, yerel yönetici ve işletmelerin gün geçtikçe bilinirliği artan Likya Yolu Rotası'nda belirlenen eksikliklerin giderilmesi ve rotanın iyileştirilmesi açısından önem arz etmektedir.

Alanyazında cinsiyete göre farklılıklara bakıldı ̆̆ında Frohlick (2005) ve Muhar vd. (2007) yaptıkları çalışmalarda dağcılık ve yürüyüş etkinliklerine en çok erkek bireylerin yöneliminin fazla olduğu sonucuna ulaşmışlardır. Çalışmada cinsiyete göre farklılıkların belirlenmesi amacıyla "Likya Yolu yürüyüşçülerinin memnuniyet düzeyi cinsiyete göre farklılık gösterir mi?" sorusu 
oluşturulmuştur. Medeni durum ile doğa sporlarına katılım arasındaki ilişkinin üzerinde pek fazla durulmasa da doğru evliliğin yaşam doyumunu artırdığı bilinmektedir (Hicks ve Platt 1970; Laws 1971). Dolayısıyla bu durumun bireylerin çevresiyle etkileşiminin yanı sıra rekreatif etkinliklere katılımını da olumlu yönde etkilediği düşünülmektedir (Ardahan ve Lapa 2011: 1335). Medeni durumun memnuniyet üzerindeki etkisi "Likya Yolu yürüyüşçülerinin memnuniyet düzeyi medeni duruma göre farklılık gösterir mi?" sorusuyla değerlendirilmiştir.

Pazarbaşı (2014) tarafından gerçekleştirilen çalışmada Likya Yolu yürüyüşüne genel itibariyle T.C. vatandaşlarının katılım sağladığı görülmektedir. Üzümcü (2018) ise yürüyüşçülerin daha çok Türkiye'den katıldıklarını vurgulamıştır. Yürüyüşçülerin uyruklarına göre farklılıkların olup olmadığ ${ }_{1}$ "Likya Yolu yürüyüşçülerinin memnuniyet düzeyi uyruğa göre farklılık gösterir mi?" sorusuyla belirlenmiştir. Alanyazında doğa sporlarına yönelik yaş gruplarına bakıldığında Brämer (2009), ileri yaştaki insanların sağlıklarına daha çok dikkat etmesi sebebiyle tercih ettiklerini vurgulamaktadır. Genç nesil ise daha çok yürüyüşün sportif ve maceracı yönüyle ilgilenmektedir. Yaş demografik değişkeninin memnuniyet üzerindeki etkisinin belirlenmesi amaciyla "Likya Yolu yürüyüşçülerinin memnuniyet düzeyi yaşa göre farklılık gösterir mi?" sorusu oluşturulmuştur.

Bir diğer demografik değişken olan öğrenim durumu, "Likya Yolu yürüyüşçülerinin memnuniyet düzeyi öğrenim durumuna göre farklılık gösterir mi?" sorusuyla değerlendirilmiştir. Çalışma örnekleminin yaklaşık yüzde 71'i yükseköğrenimini tamamlamış bireylerden oluşmaktadır. Ayrıca yürüyüşçülerin gelir düzeyine göre farklılıkların belirlenmesi amacıyla "Likya Yolu yürüyüşçülerinin memnuniyet düzeyi ortalama aylık gelir düzeyine göre farklılık gösterir mi?" sorusu oluşturulmuştur. Cerin, Leslie ve Owen (2009) öğrenim durumunun ve gelir düzeyinin ulaşımla ilgili yürüyüş sıklığını dahi etkilediğini vurgulamaktadır. Gelir düzeyi genellikle öğrenim durumu ile ilişkilendirildiğinden açık hava etkinliklerine katılımda gelir düzeyinin yüksek olduğu düşünülmektedir (Muhar vd. 2007: 10). Ancak çalışmada bu düşüncenin aksine katılımcların yarısının gelir düzeyinin 3.500 TL ve daha az olduğu görülmüştür. Clarke (1956) ve Burdge (1969), sosyal statü ile bağlantılı ve finansal ya da kültürel kaynak gerektiren etkinlikle mesleki statü ve boş zaman etkinlikleri arasında anlamlı bir ilişki olduğunu vurgulamıştır (Lee, Scott ve Floyd 2001: 429). Çalışmanın son sorusu Clarke ve Burdge' un çalışmasından yararlanılarak mesleğe göre oluşabilecek farklılıklar üzerine "Likya Yolu yürüyüşçülerinin memnuniyet düzeyi mesleğe göre farklılık gösterir mi?" şeklinde hazırlanmıştır.

\section{YÖNTEM}

Çalışmanın temel amacı, Likya Yolu Rotası'nı yürüyen turistlerin yürümüş olduğu parkur ve çevresine yönelik memnuniyet düzeylerinin belirlenmesidir. Ayrıca rotayı yürüyen turistlerin demografik özelliklerinin belirlenerek yürüyüşçü profilinin çıkarılması çalışmanın bir diğer amacını oluşturmaktadır. Çalışma ile birlikte rotanın ve rotada yer alan destinasyonların eksik yönlerinin saptanması hedeflenmiştir. Böylelikle yerli ve yabancı turistlerin ilgisini çeken Likya Yolu Rotası'nın geliştirilmesi konusunda farkındalık oluşturacağı düşünülmüştür. Ayrıca eksikliklerin giderilmesi konusunda işletmelere, yerel halka ve yerel destinasyon örgütlerinin çalışmalarına katkı sunması amaçlanmıştır.

Yerli ve yabancı Likya Yolu Rotası'nı yürüyen tüm turistler çalışmanın evreni olarak belirlenmiştir. Güncel ziyaretçi sayısı konusunda istatistiksel bir veri bulunmamaktadır. 80'den fazla şirketin grup ya da bireysel olarak ziyaretçi taşıdığ bilinmektedir (Tanrısever 2020). Bu sebeple Kültür Rotaları Derneği tarafından belirtilen 20.000 kişi çalışmanın evreni olarak belirlenmiştir. Örneklem büyüklüğünün hesaplanırken;

$$
n=\frac{\mathrm{NPQZ}^{2}}{(\mathrm{~N}-1) \mathrm{d}^{2}+\mathrm{PQZ}}
$$

formülünden yararlanılmıştır (Yamane 1967; Özer 2004). Formüle göre araştırmanın minimum örneklem büyüklüğü 377'dir. 
Çalışmada nicel yöntem benimsenmiş ve betimsel araştırma modelinden yararlanılmıştır. Akademik alanyazının taranmasıyla başlatılan süreçte, çalışmanın amaçlarına uygun çalışmalar (Güngör 2010; Pazarbaşı 2014; Tekin, Turhan ve Turhan 2018) incelenerek bir ölçek uyarlanmıştır. Uyarlanan memnuniyet ölçeğinin yer aldı̆̆ı anket öncelikle Likya Yolu Rotası yürüyüşçülerine ve ilgili akademisyenlere uygulanmıștır. Ankette öncelikle katılımcıların demografik özellikleri ve Likya Yolu yürüyüşü deneyimi öncesi ve sonrasına yönelik bilgiler öğrenilmiştir. Son olarak da katılımcıların yürüyüşlerini gerçekleştirdikleri parkur/parkurlar ve çevresine yönelik memnuniyetlerine ilişkin sorular 5'li Likert derecelendirmeli olarak yöneltilmiştir.

Likya Yolu 1999 yılında 23 yürüyüş etabı ile açılmıştır. 2015 yılına kadar yapılan düzenlemeler ve alternatif güzergâhların eklenmesiyle birlikte bu sayı 33'e çıkarılmıştır (Clow 2017). Anket uygulanma sürecinde bireylerin Ovacık'tan başlayıp, Geyikbayırı'nda biten bu 33 adet etaptan en az birini yürümüş olması esas alınmıştır. Anketler yürüyüşçülere hem yüz yüze hem e-posta yolu ile uygulandığından, tüm etaplarda yürüyüş gerçekleştiren katılımcılara ulaşılabilme olanağı sağlanmıştır. Çalışmada, memnuniyet düzeyinin katılımcıların demografik özellikleriyle ilgisinin olup olmama durumuna yönelik yedi adet sorunun yanıtı aranmaktadır. Söz konusu demografik özellikler "cinsiyet", "medeni durum", "uyruk", "yaş", "öğrenim durumu”, "ortalama aylık gelir düzeyi" ve "meslek" olarak belirlenmiştir. Anket, kolayda örnekleme yöntemi ile belirlenen 416 yürüyüşçüye uygulanmıştır.

Çalışmanın üç adet sınırlılığı bulunmaktadır. İlki çalışma alanının, alternatif güzergâhlarla birlikte toplamda 33 adet yürüyüş parkurundan oluşmasıdır. Anket yerli ve yabancı turistlere uygulanmak üzere Türkçe ve İngilizce olarak iki farklı dilde hazırlanmıştır. Veri toplama sürecinde daha çok yerli turistlere ulaşılabilmesi çalışmanın ikinci sınırlılı̆̆ını oluşturmaktadır. Son olarak veri toplama aracının uygulanma süresi 2018 yılının Eylül, Ekim ve Kasım ayı olarak s1nırlandırılmıştır. Araştırma sürecinde veri toplama aracı olarak kullanılan ölçeğin (Güngör 2010) yapısal geçerliliğini ölçmek amacı ile keşfedici faktör analizi yapıldığından bilgilerin geçerli ve güvenilir olduğu, araştırmada belirlenen örneklem grubunun evreni temsil edebileceği ve uyarlanan anket ölçeğinin, çalışmanın amaçlarına ve çalışma sorularına yanıt olabilecek nitelikte olduğu varsayılmaktadır.

\section{BULGULAR}

Katılımcıların cinsiyet, yaş, medeni durum, öğrenim durumu, ortalama aylık gelir düzeyi, meslek, hangi ülkenin vatandaşı oldukları ve yürüyüsse hangi ülkeden katılım sağladıklarına yönelik bilgiler Tablo 1'de verilmiştir.

Tabloda verildiği üzere katılımcıların yüzde $64,7^{\prime}$ sini erkek bireyler oluşturmaktadır. Daha çok 40 yaş ile üzeri ve bekârlardan oluşan katılımcıların eğitim seviyelerinin yüzde 57,2 oranında lisans mezunu olduğu görülmektedir. Ayrıca katılımcıların yüzde 49,3'ü özel sektörde çalışmaktadır ve katılımcıların yarısının ortalama aylık gelir düzeyi 3.500 TL altındadır. Katılımcıların yüzde $94^{\prime}$ ü T.C. vatandaşıdır ve yüzde 94,7 'si de yürüyüşlerine Türkiye'den katılım sağlamaktadir.

Pilot çalışma sürecinde elde edilen verilerden, anket sorularının neredeyse tamamının anlaş1labilir düzeyde olduğu sonucuna ulaşılmıştır. Uyarlanan ölçeğin faktör analizine uygunluğunun ve örneklem yeterliliğinin belirlenmesi amacıyla KMO ve Bartlett Testi uygulanmıştır (Güriş ve Astar 2019). Test sonucunda KMO değerinin 0,947 olduğu, yani örneklemin yeterli düzeyde olduğu görülmektedir. Ayrıca ulaşılan anlamlılık değerinin $<0,05$ olduğu görülmektedir. Bu durum ise verilerin faktör analizi için uygun olduğu göstermektedir. Bartlett Küresellik Testi sonucunda veri seti 0,000 düzeyinde anlamlı bulunmuştur. Ölçekte yer alan maddelerin faktör dağılımı ve güvenirlik analizi sonuçları devamında Tablo 2'deki gibidir.

Tablo 2'de görüldüğü üzere, ölçekte yer alan 49 maddeden "Likya Yolu mobil telefon uygulamaları yeterliliğ̈i", faktör yükü 0,362 ile en düşük madde olması sebebiyle çıkarılmıştır. Böylelikle ölçekteki soru sayısı 48 olarak belirlenmiştir. Açıklanan toplam varyans oranı yüzde 58,747 
Tablo 1. Katılımcıların Demografik Özelliklerine İlişkin Sıklık Analizi

\begin{tabular}{|c|c|c|c|}
\hline & & $N$ & $\%$ \\
\hline \multirow{2}{*}{ Cinsiyetiniz } & Kadın & 147 & 35,3 \\
\hline & Erkek & 269 & 64,7 \\
\hline \multirow{4}{*}{ Yaşınız } & 25 yaş ve altı & 110 & 26,4 \\
\hline & $26-32$ yaş arası & 104 & 25,0 \\
\hline & 33-39 yaş arası & 88 & 21,2 \\
\hline & 40 yaş ve üzeri & 114 & 27,4 \\
\hline \multirow{2}{*}{ Medeni durumunuz } & Bekâr & 241 & 57,9 \\
\hline & Evli & 175 & 42,1 \\
\hline \multirow{4}{*}{ Öğrenim durumunuz } & $\begin{array}{l}\text { Ortaöğretim ve } \\
\text { altı }\end{array}$ & 61 & 14,6 \\
\hline & Önlisans & 60 & 14,4 \\
\hline & Lisans & 238 & 57,2 \\
\hline & Lisansüstü & 57 & 13,7 \\
\hline \multirow{7}{*}{$\begin{array}{l}\text { Ortalama aylık gelir } \\
\text { düzeyiniz }\end{array}$} & 3.500 TL ve daha & & \\
\hline & az & & \\
\hline & 3.501-7.000 TL & 208 & 50,0 \\
\hline & arası & 140 & 33,7 \\
\hline & 7.001-10.500 TL & 42 & 10,1 \\
\hline & arası & 26 & 6,3 \\
\hline & $\begin{array}{l}\text { 10.501TL ve daha } \\
\text { fazla }\end{array}$ & & \\
\hline \multirow{5}{*}{ Mesleğiniz } & Kamu çalışanı & 74 & 17,8 \\
\hline & $\begin{array}{c}\text { Özel sektör } \\
\text { calısanı }\end{array}$ & 205 & 49,3 \\
\hline & Emekli & 45 & 10,8 \\
\hline & Öğrenci & 68 & 16,3 \\
\hline & Diğer & 24 & 5,8 \\
\hline \multirow{2}{*}{$\begin{array}{c}\text { Hangi ülkenin } \\
\text { vatandaşısınız? }\end{array}$} & T.C. & 391 & 94,0 \\
\hline & Diğer & 25 & 6,0 \\
\hline \multirow{2}{*}{$\begin{array}{l}\text { Hangi ülkeden } \\
\quad \text { katılım } \\
\text { sağlıyorsunuz? }\end{array}$} & TR & 394 & 94,7 \\
\hline & Diğer & 22 & 5,3 \\
\hline
\end{tabular}

olan ölçekte, Cronbach's Alpha iç tutarlılık katsayısı çalışmanın yüksek düzeyde güvenilir olduğunu göstermektedir.

Katılımcıların memnuniyetinin belirlenmesine yönelik uyarlanan ölçeğe, Kolmogorov-Smirnov ve Shapiro-Wilk testleri kullanılarak normallik testi uygulanmıştır. Yapılan analizle ölçeğin normal dağılım göstermediği $(\mathrm{p}<0,05)$ sonucuna ulaşılmış, bu sebeple çarpıklık ve basıklık değerlerine bakılmıştır. Analiz sonucunda çarpıklık ve basıklık değerinin 1,96 olduğu belirlenmiştir. $\mathrm{Bu}$ değerlerin +2 ve -2 arasında olması verilerin normal bir dağılım gösterdiği anlamına gelmektedir (George ve Mallery 2003).

Çalışmanın birinci sorusu "Likya Yolu yürüyüşçülerinin memnuniyet düzeyleri cinsiyetlerine göre farklılık gösterir mi?" şeklinde belirlen- miştir. İkinci soru "Likya Yolu yürüyüşçülerinin memnuniyet düzeyleri medeni durumlarına göre farklılık gösterir mi?" şeklindedir. "Likya Yolu yürüyüşçülerinin memnuniyet düzeyleri uyruklarına göre farklılık gösterir mi?" ise çalışmanın üçüncü sorusudur. Karşılaştırılacak grup sayısının iki olması sebebiyle bağımsız örneklem t-testi uygulanmış ve Tablo $3^{\prime}$ teki sonuçlar elde edilmiştir.

Uygulanan t-testi sonucunda memnuniyet ölçeğinde yer alan alt yapı, üst yapı ve görsel peyzaj gruplarının cinsiyete göre anlamlı bir farklılık göstermediği ( $p>0,05)$, ancak tanıtımın anlamlı bir farklılık gösterdiği $(\mathrm{p}<0,05)$ görülmüştür. Buna göre memnuniyet düzeyi cinsiyete göre anlamlı bir farklılık göstermektedir. Medeni durum açısından alt yapı, üst yapı, görsel peyzaj ve tanıtım gruplandırmalarına verilen cevapların ortalamalar yönünden arasında anlamlı bir farklılık olmadığ 1 görülmüştür $(p>0,05)$. Bu durum memnuniyet düzeyinin medeni duruma göre anlamlı bir farklılık içermediğini göstermektedir. Ayrıca alt yapı ile görsel peyzaj uyruğa göre anlamlı bir farklılık göstermediği $(p>0,05)$, ancak üst yapı ile tanıtımın uyruğa göre anlamlı bir farklılık gösterdiği $(\mathrm{p}<0,05)$ sonucuna ulaşılmıştır. Buna göre memnuniyet düzeyi uyruğa göre anlamlı bir farkl1lık göstermektedir.

Çalışmanın dördüncü sorusu "Likya Yolu yürüyüşçülerinin memnuniyet düzeyleri yaşlarına göre farklılık gösterir mi?" olarak belirlenmiştir. Beşinci soru ise "Likya Yolu yürüyüşçülerinin memnuniyet düzeyleri öğrenim durumlarına göre farklılık gösterir mi?" şeklindedir. Karşılaştırılacak grup sayısının ikiden fazla olması sebebiyle tek yönlü ANOVA testi uygulanmış, analiz sonucu Tablo 4'te verilmiştir.

Tablo 4'te görüldüğü üzere alt yapı, üst yapı, tanıtım ve görsel peyzaj gruplarının tüm yaş grupları ile arasında anlamlı bir farklılık olduğu görülmüştür $(p<0,05)$. Farklılıkların tespit edilebilmesi amaciyla Levene istatistik testi yapılmış ve varyans homojenliğine bakılmıştır. Levene istatistiği sonucunda, üst yapı, görsel peyzaj ve tanıtımın varyans homojenliği sağlanırken $(p>0,05)$, alt yapının varyans homojenliği sağlanamamıştır $(\mathrm{p}<0,05)$. Bu sebeple, alt yapı veri seti için Tamhane ve diğer gruplar için ise Tukey tes- 
Tablo 2. Memnuniyet Ölçeği Maddelerinin Faktör Dağılımı ve Güvenirlik Analizi Sonuçları

\begin{tabular}{|c|c|c|c|c|c|}
\hline Faktörler-Maddeler & $\begin{array}{c}\text { Faktör } \\
\text { Yükü }\end{array}$ & Özdeğer & $\begin{array}{c}\text { Açıklanan } \\
\text { Varyans } \\
\text { Oranı }\end{array}$ & Ortalama & Güvenirlik \\
\hline Alt Yapı & & 20,217 & 41,259 & 3,161 & ,900 \\
\hline Yararlı turistik bilgilere ulaşılabilirlik & 680 & & & & \\
\hline Kişisel güvenlik ve destinasyon güvenilirliği & ,668 & & & & \\
\hline Turistik yerlerin emniyet ve güvenliği & 653 & & & & \\
\hline Kültür ve Turizm Bakanlığı işaretlemeleri & 637 & & & & \\
\hline İnternet erişimi & ,555 & & & & \\
\hline Sağılık hizmetlerine erişebilirlik & ,549 & & & & \\
\hline Yürüyüş etaplarının güvenilirliği & ,546 & & & & \\
\hline Yönlendirme levhaları & ,535 & & & & \\
\hline Su kaynaklarının yeterliliği &, 524 & & & & \\
\hline Ziyaret edilen yerlerdeki lavaboların temizliği &, 506 & & & & \\
\hline Uluslararası işaretlemeler (kırmızı-beyaz işaretlemeler) & 478 & & & & \\
\hline Ulaşım hizmetleri & ,471 & & & & \\
\hline Yürüyüş etaplarının temizliği & ,468 & & & & \\
\hline Likya Yolu mobil telefon uygulamaları yeterliliği & ,362 & & & & \\
\hline Üst Yapı & & 3,441 & 7,022 & ,938 & 3,172 \\
\hline Eserlerin tarihi dokuya uygun restorasyonu & ,775 & & & & \\
\hline Tarihi yapıların ve eserlerin korunması & ,757 & & & & \\
\hline Eserler hakkında bilgilendirme panoları & ,732 & & & & \\
\hline Açık hava aktiviteleri çeşitliliği & ,709 & & & & \\
\hline Tarihi mekânlara erişebilirlik & ,708 & & & & \\
\hline Kişisel ihtiyaçları temin edebilme & 694 & & & & \\
\hline Kentin ve çevresinin modernliği & 694 & & & & \\
\hline Turist bilgilendirme merkezlerinin mevcudiyeti & 690 & & & & \\
\hline Alısveriş mekânları yeterliliği & ,671 & & & & \\
\hline Yerel yönetimin duyarlııı̆ı & 653 & & & & \\
\hline Kültürel etkinlikler ve festivaller & 631 & & & & \\
\hline Plajların kalitesi & 625 & & & & \\
\hline Yiyecek-içecek işletmeleri yeterliliği & ,613 & & & & \\
\hline Konaklama imkânları &, 597 & & & & \\
\hline İşletmelerde hizmet kalitesi &, 552 & & & & \\
\hline İşletmelerdeki fiyatların uygunluğu & ,513 & & & & \\
\hline Yerel halkın genel tavrı &, 503 & & & & \\
\hline Görsel peyzaj & & 2,937 & 5,995 & ,914 & 3,623 \\
\hline İklim koşullarının rekreatif etkinlikler için uygunluğu & ,710 & & & & \\
\hline Fauna çeşitliliğinin yürüyüş için uygunluğu & 680 & & & & \\
\hline Fauna çeşitliğinin yeterliliği & 675 & & & & \\
\hline Flora çeşitliliğinin yürüyüş için uygunluğu & 669 & & & & \\
\hline Fauna (hayvan türleri) bilgilendirme panoları & ,667 & & & & \\
\hline İklim koşullarının yürüyüş için uygunluğu & 647 & & & & \\
\hline Flora çeşitliliğinin yeterliliği & ,647 & & & & \\
\hline Flora (bitki türleri) bilgilendirme panoları & 643 & & & & \\
\hline İklim koşullarının kamp yapmaya uygunluğu & ,599 & & & & \\
\hline
\end{tabular}


Tablo 2. Memnuniyet Ölçeği Maddelerinin Faktör Dağılımı ve Güvenirlik Analizi Sonuçları (Devam)

\begin{tabular}{|c|c|c|c|c|c|}
\hline İklim koşullarının kamp yapmaya uygunluğu & ,599 & & & & \\
\hline Tanıtım & & 2,191 & 4,471 & ,951 & 3,126 \\
\hline Kültürel çekiciliklerin tanıtımı & 791 & & & & \\
\hline Doğal çekiciliklerin tanıtımı & ,787 & & & & \\
\hline Tarihi ve kültürel değerlerin tanıtımı & 779 & & & & \\
\hline Destinasyonların tanıtımı & 772 & & & & \\
\hline Yapılabilecek rekreatif etkinliklerin tanıtımı & ,753 & & & & \\
\hline Mavi bayraklı plajların tanıtımı & ,718 & & & & \\
\hline Yakın çevredeki konaklama işletmelerinin tanıtımı & ,712 & & & & \\
\hline Yakın çevredeki yiyecek-içecek işletmelerinin tanıtımı & ,653 & & & & \\
\hline Likya Yolu mobil telefon uygulamalarının tanıtımı & ,475 & & & & \\
\hline
\end{tabular}

Tablo 3. Memnuniyet Ölçeğinin Cinsiyet, Medeni Durum ve Uyruğa Göre Bağımsız Örneklem T Testi Sonuçları

\begin{tabular}{|c|c|c|c|c|c|c|}
\hline Cinsiyet & & $N$ & Ortalama & SS & $T$ & $P$ \\
\hline \multirow{2}{*}{ Genel } & Kadın & 147 & 3,3267 & ,73269 & \multirow{2}{*}{1,499} & \multirow{2}{*}{ 135 } \\
\hline & Erkek & 269 & 3,2156 & ,71658 & & \\
\hline \multirow{2}{*}{ Alt Yapı } & Kadın & 147 & 3,2562 & ,76731 & \multirow{2}{*}{1,383} & \multirow{2}{*}{ 167 } \\
\hline & Erkek & 269 & 3,1490 & ,74936 & & \\
\hline \multirow[t]{2}{*}{ Üst Yapı } & Kadın & 147 & 3,2449 & ,74680 & \multirow{2}{*}{1,453} & \multirow{2}{*}{ 147 } \\
\hline & Erkek & 269 & 3,1319 & ,76497 & & \\
\hline \multirow[t]{2}{*}{ Görsel Peyzaj } & Kadın & 147 & 3,6327 & ,97696 & \multirow{2}{*}{158} & \multirow{2}{*}{,875 } \\
\hline & Erkek & 269 & 3,6175 & 85347 & & \\
\hline \multirow[t]{2}{*}{ Tanıtım } & Kadın & 147 & 3,2676 & ,99149 & \multirow{2}{*}{2,077} & \multirow{2}{*}{,038 } \\
\hline & Erkek & 269 & 3,0492 & 1,04338 & & \\
\hline Medeni Durum & & $N$ & Ortalama & SS & $T$ & $P$ \\
\hline \multirow[t]{2}{*}{ Genel } & Bekâr & 241 & 3,2857 & ,71901 & \multirow{2}{*}{1,429} & \multirow{2}{*}{ 154 } \\
\hline & Evli & 175 & 3,2124 & ,72930 & & \\
\hline \multirow[t]{2}{*}{ Alt Yapı } & Bekâr & 241 & 3,2320 & ,72936 & \multirow{2}{*}{1,348} & \multirow{2}{*}{ 178 } \\
\hline & Evli & 175 & 3,1248 & 79041 & & \\
\hline \multirow[t]{2}{*}{ Üst Yapı } & Bekâr & 241 & 3,2145 & ,72510 & \multirow{2}{*}{,- 074} & \multirow{2}{*}{ 941 } \\
\hline & Evli & 175 & 3,1129 & 80315 & & \\
\hline \multirow[t]{2}{*}{ Görsel Peyzaj } & Bekâr & 241 & 3,6201 & ,90780 & \multirow{2}{*}{,696 } & \multirow{2}{*}{,487 } \\
\hline & Evli & 175 & 3,6267 & ,88666 & & \\
\hline \multirow[t]{2}{*}{ Tanıtım } & Bekâr & 241 & 3,1563 & 1,00042 & \multirow{2}{*}{1,021} & 200 \\
\hline & Evli & 175 & 3,0851 & 1,06971 & & \\
\hline Uyruk & & $N$ & Ortalama & SS & $T$ & $P$ \\
\hline Genel & T.C. & 391 & 3,2380 & ,73269 & 1881 & 060 \\
\hline & Diğer & 25 & 3,5183 & ,71658 & & \\
\hline Alt Yapı & T.C. & 391 & 3,1773 & ,76731 & 1021 & 200 \\
\hline & Diğer & 25 & 3,3367 & ,74936 & & \\
\hline Üst Yapı & T.C. & 391 & 3,1489 & ,74680 & 201 & 015 \\
\hline & Diğer & 25 & 3,5294 & ,76497 & $2,+4+2$ & נט, \\
\hline Görsel Peyzaj & T.C. & 391 & 3,6192 & ,97696 & -328 & 743 \\
\hline & Diğer & 25 & 3,6800 & 85347 & - &, 143 \\
\hline Tanıtım & T.C. & 391 & 3,0995 & ,99149 & & \\
\hline & Diğer & 25 & 3,5467 & 1,04338 & $-2,115$ & ,035 \\
\hline
\end{tabular}


Tabblo 4. Memnuniyet Ölçeğinin Yaş ve Öğrenim Durumuna Göre Tek Yönlü_ANOVA Testi Sonụçları

\begin{tabular}{|c|c|c|c|c|c|c|}
\hline & 25 yaş ve altı & 110 & 3,4824 & ,70016 & \multirow{4}{*}{21,486} & \multirow{4}{*}{000} \\
\hline \multirow{4}{*}{ Genel } & $26-32$ yaş arası & 104 & 3,4371 & ,75477 & & \\
\hline & 33-39 yaş arası & 88 & 3,2985 & ,61827 & & \\
\hline & 40 yaş ve üzeri & 114 & 2,8353 & ,61269 & & \\
\hline & 25 yaş ve altı & 110 & 3,3848 & 79065 & \multirow{4}{*}{11,512} & \multirow{4}{*}{,000 } \\
\hline \multirow{3}{*}{ Alt Yapı } & $26-32$ yaş arası & 104 & 3,3165 & ,81678 & & \\
\hline & 33-39 yaş arası & 88 & 3,2112 & ,60608 & & \\
\hline & 40 yaş ve üzeri & 114 & 2,8589 & ,66760 & & \\
\hline \multirow{4}{*}{ Üst Yapı } & 25 yaş ve altı & 110 & 3,4118 & ,69446 & \multirow{4}{*}{20,789} & \multirow{4}{*}{,000 } \\
\hline & 26-32 yaş arası & 104 & 3,3117 & 76076 & & \\
\hline & 33-39 yaş arası & 88 & 3,2774 & 69107 & & \\
\hline & 40 yaş ve üzeri & 114 & 2,7312 & ,69292 & & \\
\hline \multirow{4}{*}{ Görsel Peyzaj } & 25 yaş ve altı & 110 & 3,8455 & 86775 & \multirow{4}{*}{13,761} & \multirow{4}{*}{,000 } \\
\hline & $26-32$ yaş arası & 104 & 3,8397 & 96080 & & \\
\hline & 33-39 yaş arası & 88 & 3,6326 & ,80165 & & \\
\hline & 40 yaş ve üzeri & 114 & 3,2027 & ,79291 & & \\
\hline \multirow{4}{*}{ Tanıtım } & 25 yaş ve altı & 110 & 3,3980 & ,89945 & \multirow{4}{*}{17,503} & \multirow{4}{*}{,000 } \\
\hline & $26-32$ yaş arası & 104 & 3,4412 & ,99832 & & \\
\hline & 33-39 yaş arası & 88 & 3,0922 & 1,06310 & & \\
\hline & 40 yaş ve üzeri & 114 & 2,6033 & 94512 & & \\
\hline \multirow[t]{2}{*}{ Öğrenim Durumu } & & $\mathrm{N}$ & Ortalama & SS & $\mathrm{F}$ & $P$ \\
\hline & Ortaöğretim ve altı & 61 & 3,2609 & ,84258 & \multirow{4}{*}{ 623 } & \multirow{4}{*}{ 601 } \\
\hline \multirow[t]{4}{*}{ Genel } & Önlisans & 60 & 3,3681 & 67022 & & \\
\hline & Lisans & 238 & 3,2252 & ,72084 & & \\
\hline & Lisansüstü & 57 & 3,2529 & 65382 & & \\
\hline & Ortaöğretim ve altı & 61 & 3,2254 & 91253 & \multirow{4}{*}{ 167 } & \multirow{4}{*}{ 919 } \\
\hline \multirow{3}{*}{ Alt Yapı } & Önlisans & 60 & 3,2306 & ,74288 & & \\
\hline & Lisans & 238 & 3,1702 & ,74084 & & \\
\hline & Lisansüstü & 57 & 3,1696 & ,75657 & & \\
\hline \multirow{4}{*}{ Üst Yapı } & Ortaöğretim ve altı & 61 & 3,1466 & 83719 & \multirow{4}{*}{,808 } & \multirow{4}{*}{,490 } \\
\hline & Önlisans & 60 & 3,3069 & 74384 & & \\
\hline & Lisans & 238 & 3,1396 & ,76064 & & \\
\hline & Lisansüstü & 57 & 3,1909 & ,68467 & & \\
\hline & Ortaöğretim ve altı & 61 & 3,6138 & 99269 & & \\
\hline Görsel Peyzai & Önlisans & 60 & 3,7037 & 87001 & 132 & 730 \\
\hline & Lisans & 238 & 3,5864 & ,90468 &, 433 & , 130 \\
\hline & Lisansüstü & 57 & 3,6998 & ,79930 & & \\
\hline & Ortaöğretim ve altı & 61 & 3,1712 & 1,09555 & & \\
\hline Tanıtım & Önlisans & 60 & 3,3463 & 91809 & 1297 & 275 \\
\hline & Lisans & 238 & 3,0859 & 1,02695 & & \\
\hline & Lisansüstü & 57 & 3,0156 & 1,06914 & & \\
\hline
\end{tabular}

tine bakılmıştır. Tamhane ve Tukey testi analizleri sonucunda 40 yaş ve üzeri grubun, diğer tüm gruplarla arasında anlamlı bir farklılık bulunduğu tespit edilmiştir. Buna göre memnuniyet düzeyi yaşa göre farklılık göstermektedir.

Beşinci sorunun analizine yönelik uygulanan ANOVA testi sonucu ulaşılan ortalamalar; alt yapı, üst yapı, görsel peyzaj ve tanıtım gruplandır- maları ile öğrenim grupları ile arasında anlamlı bir farklılık olmadığı görülmüştür $(p>0,05)$. Buna göre Likya Yolu yürüyüşçülerinin memnuniyetleri öğrenim durumlarına göre farklılık göstermemektedir.

Çalışmanın altıncı sorusu "Likya Yolu yürüyüşçülerinin memnuniyet düzeyleri ortalama aylık gelir düzeylerine göre farklılık gösterir mi?" 
Tablo 5. Memnuniyet Ölçeğinin Ortalama Aylık Gelir Düzeyi ve Mesleğe Göre Tek Yönlü ANOVA Testi Sonuçları

\begin{tabular}{|c|c|c|c|c|c|c|}
\hline \multicolumn{2}{|c|}{ Ortalama Aylık Gelir Düzeyi } & \multirow{2}{*}{$\frac{N}{208}$} & \multirow{2}{*}{$\frac{\text { Ortalama }}{3,2782}$} & \multirow{2}{*}{$\frac{\text { SS }}{, 74640}$} & \multirow[t]{2}{*}{$F$} & \multirow[t]{2}{*}{$P$} \\
\hline \multirow{4}{*}{ Genel } & 3.500 TL ve daha az & & & & & \\
\hline & 3.501-7.000 TL arası & 140 & 3,2735 & 75417 & \multirow{3}{*}{1,237} & \multirow{3}{*}{,296 } \\
\hline & 7.001-10.500 TL arası & 42 & 3,2381 & ,58663 & & \\
\hline & 10.501 TL ve daha fazla & 26 & 2,9944 &, 51910 & & \\
\hline \multirow{4}{*}{ Alt Yapı } & 3.500 TL ve daha az & 208 & 3,2051 & ,77764 & \multirow{4}{*}{,444 } & \multirow{4}{*}{,722 } \\
\hline & 3.501-7.000 TL arası & 140 & 3,1827 & ,79302 & & \\
\hline & 7.001-10.500 TL arası & 42 & 3,0694 & ,64232 & & \\
\hline & 10.501 TL ve daha fazla & 26 & 3,2532 &, 53928 & & \\
\hline \multirow{4}{*}{ Üst Yapı } & 3.500 TL ve daha az & 208 & 3,2005 & ,77566 & \multirow{4}{*}{1,329} & \multirow{4}{*}{,265 } \\
\hline & 3.501-7.000 TL arası & 140 & 3,2025 & ,77809 & & \\
\hline & 7.001-10.500 TL arası & 42 & 3,0840 & ,65350 & & \\
\hline & 10.501 TL ve daha fazla & 26 & 3,9186 & ,66240 & & \\
\hline \multirow{4}{*}{ Görsel Peyzaj } & 3.500 TL ve daha az & 208 & 3,6512 & ,94214 & \multirow{4}{*}{2,294} & \multirow{4}{*}{,077 } \\
\hline & 3.501-7.000 TL arası & 140 & 3,6278 & ,89971 & & \\
\hline & 7.001-10.500 TL arası & 42 & 3,7328 & ,74234 & & \\
\hline & 10.501 TL ve daha fazla & 26 & 3,1923 & ,63987 & & \\
\hline \multirow{4}{*}{ Tanıtım } & 3.500 TL ve daha az & 208 & 3,1522 & 1,01567 & \multirow{4}{*}{3,337} & \multirow{4}{*}{,019 } \\
\hline & 3.501-7.000 TL arası & 140 & 3,1754 & 1,06023 & & \\
\hline & 7.001-10.500 TL arası & 42 & 3,2116 & 1,00250 & & \\
\hline & 10.501 TL ve daha fazla & 26 & 2,5171 & ,85776 & & \\
\hline Meslek & & $\mathrm{N}$ & Ortalama & SS & $\mathrm{F}$ & $P$ \\
\hline \multirow{5}{*}{ Genel } & Kamu çalışanı & 74 & 3,3711 & ,68837 & & \\
\hline & Özel sektör çalışanı & 205 & 3,2322 & ,71405 & & \\
\hline & Emekli & 45 & 2,7301 & 65999 & 10,849 &, 000 \\
\hline & Öğrenci & 68 & 3,5766 &, 62642 & & \\
\hline & Diğer & 24 & 3,1623 & ,73318 & & \\
\hline & Kamu çalışanı & 74 & 3,2759 & ,76226 & & \\
\hline & Özel sektör çalışanı & 205 & 3,1764 & ,75102 & & \\
\hline Alt Yapı & Emekli & 45 & 2,6685 & 63452 & 8,594 &, 000 \\
\hline & Öğrenci & 68 & 3,4743 & 69203 & & \\
\hline & Diğer & 24 & 3,1869 & 72019 & & \\
\hline & Kamu çalışanı & 74 & 3,3021 & 70711 & & \\
\hline & Özel sektör çalışanı & 205 & 3,1570 & ,73742 & & \\
\hline Üst Yapı & Emekli & 45 & 2,6092 & ,77717 & 10,847 &, 000 \\
\hline & Öğrenci & 68 & 3,4913 & 65863 & & \\
\hline & Diğer & 24 & 3,0466 & ,76696 & & \\
\hline & Kamu çalışanı & 74 & 3,7132 & ,82454 & & \\
\hline & Özel sektör çalışanı & 205 & 3,5772 & ,92793 & & \\
\hline Görsel Peyzaj & Emekli & 45 & 3,1975 & ,92232 & 4,852 & ,001 \\
\hline & Öğrenci & 68 & 3,9134 & 81827 & & \\
\hline & Diğer & 24 & 3,7083 & ,71994 & & \\
\hline & Kamu çalışanı & 74 & 3,2688 & 1,03319 & & \\
\hline & Özel sektör çalışanı & 205 & 3,0976 & ,98241 & & \\
\hline Tanıtım & Emekli & 45 & 2,5506 & 1,05886 & 7,849 &, 000 \\
\hline & Öğrenci & 68 & 3,5490 & 82745 & & \\
\hline & Diğer & 24 & 2,8148 & 1,29770 & & \\
\hline
\end{tabular}

olarak belirlenmiştir. Çalışmanın son sorusu ise "Likya Yolu yürüyüşçülerinin memnuniyet düzeyleri mesleklerine göre farklılık gösterir mi?" şeklindedir. Sorular tek yönlü ANOVA testi ile değerlendirilmiş, elde edilen sonuçlar Tablo 5'te verilmiştir.
Tablo 5'te verilen tek yönlü ANOVA testi sonucunda alt yapı, üst yapı ve görsel peyzaj gruplarının ortalama aylık gelir düzeyi ile arasında anlamlı bir farklılık olmadığı ( $>00,05)$, ancak tanıtımın ortalama aylık gelire göre farklılık gösterdiği 
$(\mathrm{p}<0,05)$ saptanmıştır. Tanıtım grubu farklılığının saptanması amaciyla yapilan Tukey testi sonucunda, gelir düzeyi 10.501 TL ve daha fazla olan grubun diğer tüm gruplarla arasında anlamlı bir farklılık olduğu tespit edilmiştir. Buna göre memnuniyet düzeyi ortalama aylık gelir düzeyine göre anlamlı bir farklılık göstermektedir.

Memnuniyet ölçeğinin meslek gruplarına göre yapılan tek yönlü ANOVA testi sonucunda alt yapı, üst yapı, tanıtım, görsel peyzaj ve genel ile tüm meslek grupları arasında anlamlı bir farklılık olduğu saptanmış $(p<0,05)$, farklılığın belirlenmesine yönelik Tamhane ve Tukey testleri uygulanmıştır. Test sonucu alt yapı, üst yapı ve tanitımda; emeklilerin, tüm meslek gruplarıyla, öğrencilerin de emeklilerin yanı sıra özel sektör çalışanlarıyla arasında anlamlı bir farklılık olmadığını göstermektedir. Ayrıca görsel peyzajda, emeklilerin kamu çalışanları ve öğrencilerle arasında ortalamalar yönünden anlamlı bir farklılık olduğu tespit edilmiştir. Bu durum memnuniyet düzeyinin mesleğe göre anlamlı bir farklılık içerdiğini göstermektedir.

\section{SONUÇ VE ÖNERILER}

Hayat standartlarının değişimiyle birlikte bireylerin istekleri ve beklentileri farklılık göstermeye başlamıştır. İşletmelerin bu durumdan en az zararla çıkabilmesi için hedef kitlesini tanıması ve talebe yönelik stratejilerin geliştirmesi gerekmektedir. İşletmeler gibi destinasyonların da ziyaretçilerine yönelik birtakım tanımlayıcı faaliyetler sürdürmesi ve bu faaliyetlere yönelik memnuniyeti sağlaması gerekmektedir. Bu çalışma, Türkiye' nin işaretlenen ilk kültür rotası olan Likya Yolu Rotası'nı yürüyen turistlerin, rotanın sahip olduğu olanaklara yönelik memnuniyetlerinin belirlenmesini esas edinmiştir.

Elde edilen veriler ışığında, Likya Yolu'na yönelik memnuniyetin yüksek oranda sağlandı $\breve{g} 1$ görülmüştür. Çalışmasını Likya Yolu'nu yürüyen turistlerin memnuniyetin düzeyi üzerinde gerçekleştiren Pazarbaşı (2014), genel memnuniyetin tekrar ziyaret etme niyeti üzerinde negatif bir etkide bulunduğu sonucuna ulaşmıştır. Ancak bu çalışmada, tıpkı daha önce yapılan çalışmalarda olduğu gibi (Baker ve Crompton 2000;
Kozak ve Rimmington 2000; Duman ve Öztürk 2005; Cam 2011; Ashton 2018) genel memnuniyetin tekrar ziyaret etme üzerinde olumlu bir etkisi olduğu belirlenmiştir.

Yürüyüşçülerin değerlendirmelerine göre; rota çevresinde yaşanan terör olaylarına rağmen en fazla güvenlik konusunda memnun oldukları anlaşılmıştır. Oluşan güvenin sürdürülmesine yönelik olası durumlarda gerekli bilgilendirmeler sağlanarak, güvenlik önemleri artırılabilir. Su kaynaklarına erişim başta olmak üzere, sağlık hizmetlerine ve internete erişim konusunda ise büyük oranda sorun yaşanmaktadır. Yürüyüşçülerin ortak sorunlarından bir diğeri temizlik konusudur. Çevredeki işletmelerin atıkları ve yapılan rekreatif etkinlikler sonrası oluşan kirliliğe yönelik yeterli çalışma yapılmamaktadır. Yürüyüşçülerin açık hava etkinliklerinin daha sık yapılması yönündeki taleplerinin gerçekleştirilerek, etkinlik sonrası oluşabilecek çevre kirliliğine yönelik tedbirler alınabilir. Likya Yolu sahip olduğu flora ve fauna zenginliğiyle ön plana çımaktadır. Bu zenginliğe rağmen rota üzerinde ziyaretçilerin bilgilendirilmesi amacıyla konulması gereken flora ve fauna panoları bulunmamaktadır. Panoların yanı sıra rota üzerindeki yönlendirme levhaları da büyük oranda eksik olmakla birlikte hâlihazırdaki levhaların da yenilenmeye ihtiyacı vardır.

Yürüyüşçüler, rota üzerinde bulunan konaklama, yiyecek-içecek ve hizmet veren diğer kurum ve kuruluşların sunduğu ürün çeşitliliğinin yeterli olmadığ $\breve{1}$ halde yüksek fiyat politikası uyguladıkları konusunda hemfikirdir. Ürün çeşitliliğinin artırılmasının yanı sıra hizmet kalitesinin ve hijyen konusundaki hassasiyetin üst seviyede tutulması gerekmektedir. Bu doğrultuda sunulan hizmet kalitesiyle orantılı olarak fiyat düzenlemesi yapması önerilmektedir. Yürüyüşçülerin görüşleri doğrultusunda destinasyonların ve konaklama işletmelerinin tanıtımının yapıldığı, ancak mobil uygulamalara yönelik tanıtımının çok fazla yapılmadığ 1 sonucuna ulaşılmıştır. Anketin uygulandığı dönemde Likya Yolu'na yönelik bir mobil uygulama bulunmamaktadır. Ancak kısa bir süre sonra üç farklı kültür rotası için mobil uygulama geliştirilmiştir. 


\section{KAYNAKÇA}

Ashton, A. S. (2018). Spiritual Retreat Tourism Development in the Asia Pacific Region: Investigating the Impact of Tourist Satisfaction and Intention to Revisit: A Chiang Mai, Thailand Case Study, Asia Pacific Journal of Tourism Research, 23 (11): 1098- 1114.

Baker, D. A. ve Crompton, J. L. (2000). Quality, Satisfaction and Behavioral Intentions, Annals of Tourism Research, 27 (3): 785-804.

Baştemur, C. (2011). A New Destination for Alternative Tourism; Lycian Way, International Conference on Tourism (ICOT) (ss. 76-83). Yunanistan.

Brämer, R. (2009). Profilstudie Wandern ‘08-1. Basismodul "Wer Wandert Warum?, https://www.wanderforschung. de/WF/wanderstudien/profilstudien-wandern-lang.html, Erişim tarihi: 10 Şubat 2020.

Briedenhann, J. ve Wickens, E. (2004). Tourism Routes As a Tool For The Economic Development of Rural AreasVibrant Hopeor Impossible Dream?, Tourism Management, 25 (1): 71-79.

Buluk, B. (2016). Online Seyahat Acenteleri Aracılığıyla Seyahat Satın Almada Turist Memnuniyet: İstanbul Örneği (Basılmamış Yüksek Lisans Tezi). Çanakkale: Çanakkale Onsekiz Mart Üniversitesi Sosyal Bilimler Enstitüsü, Turizm İşletmeciliği Ana Bilim Dalı.

Burdge, R. (1969). Levels of Occupational Prestige and Leisure Activity, Journal of Leisure Research,1: 262-274.

Cam, T. T. A. (2011). Explaining Tourist Satisfaction and Intentionto Re-visit Nha Trang, Vietnam (Basılmamış Yüksek Lisans Tezi). Norway: The Norwegian College of Fishery Science University of Tromso Vietnam: Nha Trang Üniversitesi.

Cerin, E., Leslie, E. Ve Owen, N. (2009). Explaining SocioEconomic Status Differences Inwalking for Transport: An Ecological Analysis of Individual, Socialand Environmental Factors, Social Science \& Medicine, 68 (6): 1013-1020.

Clarke, A. (1956). The Use of Leisure and Its Relations to Levels of Occupational Prestige, American Sociological Review, 21: 301-132.

Clow, K. (2017). Türkiye'nin İlk Uzun Mesafeli Yürüyüş Rotası Likya Yolu (Çev. H. Eryurt). İstanbul: Hil Yayın.

Demirkol, C., Salha, H. ve Cinnioğlu, H. (2016). Trakya Bağ Rotasına Gelen Turistlerin Profilinin Belirlenmesine Yönelik Bir Araştırma, Balkan ve Yakın Doğu Sosyal Bilimler Dergisi, 2 (4): 109-120.

Duman, T. ve Öztürk, A. B. (2005). Yerli Turistlerin Mersin Kizkalesi Destinasyonu ve Tekrar Ziyaret Niyetleri ile İlgili Algılamaları Üzerine Bir Araştırma, Anatolia: Turizm Araştırmaları Dergisi, 16 (1): 9-23.

George, D. ve Mallery, M. (2003). SPSS for Windows Step by Step: A Simple Guide and Reference. Boston: Allyn \& Bacon.

Güngör, E. (2010). Turistik Yörelerden Memnuniyet ve Geleceğe Yönelik Ziyaretçi Davranışları: Antalya Örneği. (Basılmamış Doktora Tezi). Kayseri: Erciyes Üniversitesi Sosyal Bilimler Enstitüsü, İşletme Ana Bilim Dalı.

Güriş, S. ve Astar, M. (2019). Bilimsel Araştırmalarda SPSS ile Istatistik. İstanbul: Der Yayınları.
Hicks, M. W. ve Platt, M. (1970). Marital Happiness and Stability: A Review of the Research in the Sixties, Journal of Marriage and the Family, 32: 553-574.

Frohlick, S. (2005). That Playfulness of White Masculinity: Mediating Masculinities and Adventure at Mountain Film Festivals, Tourist Studies, 5 (2): 175-193.

Karataş, E. (2015). ÇEKÜL Vakfı Kültür Rotaları Planlama Rehberi. İstanbul: Tarihi Kentler Birliği Yayınları.

Kılıç, İ. ve Pelit, E. (2004). Yerli Turistlerin Memnuniyet Düzeyleri Üzerine Bir Araştırma, Anatolia: Turizm Araştırmaları Dergisi, 15 (2): 113-124.

Kozak, M. ve Rimmington, M. (2000). Tourist Satisfaction with Mallorca, Spain as An Off-Season Holiday Destination, Journal of Travel Research, 38: 260-269.

Kulözü, N. (2009). St Paul Yolu (Perge-Antalya/Yalvaç Pisidia Antiocheia) ve Yakın Çevresinin Turizm ve Rekreasyon Kullanımına Yönelik Peyzaj Potansiyelinin Saptanması Üzerine Bir Araştırma. (Basılmamış Yüksek Lisans Tezi). Ankara: Ankara Üniversitesi Fen Bilimleri Enstitüsü, Peyzaj Mimarlığı Ana Bilim Dalı.

Laws, J. L. (1971). A Feminist Review of Marital Adjustment Literature: The Rape of Locke, Journal of Marriage and the Family, 33: 483-516.

Lee, J. H., Scott, D. ve Floyd, M. F. (2001). Structural Inequalities in Outdoor Recreation Participation: A Multiple Hierarchy Stratification Perspective, Journal of Leisure Research, 33 (4): 427-449.

Meyer, D. (2004). Tourism Routes and Gateways: Key Issues for The Development of Tourism Routesand Gateways and Their Potential for Pro-poor Tourism, https:// www.researchgate.net/publication/242371864_Key_issues_for_the_development_of tourism_routes_and_gateways_ and_their_potential_for_Pro-Poor_Tourism, Erişim Tarihi: 5 Şubat 2020.

Muhar, A., Schauppenlehner, T., Brandenburg, C. ve Arnberger, A. (2007). Alpine Summer Tourism: The Mountaineers' Perspective and Consequences for Tourism Strategies in Austria, Forest Snow and Landscape Research, 81 (7): 7-17.

Özer, H. (2004). Nitel Değ̊̆işkenli Ekonometrik Modeller: Teori ve Bir Uygulama. Ankara: Nobel Yayın Dağıtım.

Özgen, Ö. (2000). Kapadokya'yı Ziyaret Eden Turistlerin Genel Seyahat Motivasyonları ve Tatmin Olma Durumlar1, Anatolia Turizm Araştırmaları Dergisi, 11 (2): 12-20.

Parasuraman, A., Zeithaml, V. A. ve Berry, L. L. (1994). Reassessment of Expectations as a Comparison Standard in Measuring Service Quality: Implications for Further Research, Journal of Marketing, 58: 120-135.

Pazarbaşı, G. (2014). Likya Yolu'nu Yürüyen Turistlerin Seyahat Motivasyonları ve Memnuniyet Düzeylerini Belirlemeye Yönelik Bir Araştırma. (Basılmamış Yüksek Lisans Tezi). Mersin: Mersin Üniversitesi Sosyal Bilimler Enstitüsü, Turizm İşletmeciliği Ana Bilim Dalı.

Pizam A., Neumann Y. ve Reichel A. (1978). Dimentions of Tourist Satisfaction With a Destination Area, Annals of Tourism Research, 5 (3): 314-322.

Puczkó, L. ve Rátz, T. (2006). Trailing Goethe, Humbertand Ulysses: Cultural Routes in Tourism. İçinde Richards, G. (Editör), Cultural Tourism: Global and Local Perspectives (ss. 131-143). Londra: Psychology Press. 
Tanrısever, C. (2020). Kültür Rotacılığını Başlatan Kadın Kate Clow. İçinde Kozak, N. ve Kozak, M. (Editörler), Turizme Kanat Gerenler. Ankara: Detay Yayıncilık.

Tekin, Ö. A., Turhan, A. A. ve Turhan, E. A. (2018). Helal Turizm Turist Profili: Antalya Destinasyonu 2017. Müstakil Sanayici ve İş adamları Derneği (MÜSİAD), Uluslararası Helal Turizm Derneği (IHATO), https://www.researchgate.net/publication/325528947_Helal_Turizm_Turist_Profili_Antalya Destinasyonu_-_2017, Erişim tarihi: 17 Ocak 2020.
Turgut, İ. ve Clow, K. (2010). Likya Yolu'nda Yürümek. İstanbul: Mart Matbaacilik.

Üzümcü, O. O. (2018). Gastronomi Kültürü ve Gastronomi Turizmi Açısından Likya Bölgesini Ziyaret Eden Turistler Üzerine Bir İnceleme. (Basılmamış Yüksek Lisans Tezi). Gaziantep: Gaziantep Üniversitesi Sosyal Bilimler Enstitüsü, Gastronomi ve Mutfak Sanatları Ana Bilim Dall.

Yamane, T. (1967). Elementary Sampling Theory. Englewood Cliffs, New Jersey: Prentice-Hall, Inc.
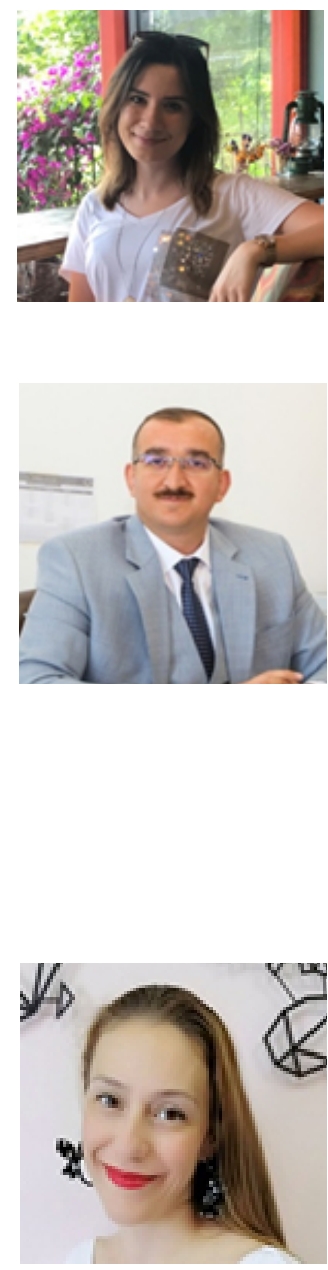

Burcu TÜTÜNCÜ

Lisansının ilk iki yılını Akdeniz Üniversitesi Turizm Fakültesi Turizm İşletmeciliği Bölümü'nde tamamladı (2015). Daha sonra yatay geçiş yaparak Ondokuz Mayıs Üniversitesi Turizm Fakültesi Turizm İşletmeciliği Bölümü’nden mezun oldu (2017). Yüksek lisansını Kastamonu Üniversitesi Turizm İşletmeciliği Ana Bilim Dalı'ndan “Likya Yolu’nu Yürüyen Turistlerin Memnuniyet Düzeyi" adlı çalışması ile aldı (2019). Yüksek lisans öğrenimi sürecinde başlayan çeşitli konulardaki akademik çalışmaları halen devam etmektedir. Temel çalışma alanları, turizm işletmeciliği ve turizm pazarlamasıdır.

\section{Hüseyin PAMUKÇU}

Niğde Üniversitesi Ulukışla Meslek Yüksekokulu Turizm ve Otel İşletmeciliği Bölümü'nden önlisans derecesi ile mezun oldu (2007). Lisans derecesini ise Mustafa Kemal Üniversitesi Turizm İşletmeciliği ve Otelcilik Yüksekokulu'ndan aldı (2011). Lisans eğitiminin son yılını ise Erasmus Programı kapsamında Uluslararası Değişim Öğrencisi olarak Macaristan Kodolanyi Janos Foiskola Üniversitesi'nde tamamladı. Erasmus programı ile 14 farklı Avrupa ülkesinde çeşitli turistik faaliyetlerde bulundu. Afyon Kocatepe Üniversitesi Sosyal Bilimler Enstitüsü İşletme Ana Bilim Dalı'ndan yüksek lisans derecesi ile bilim uzmanı olmuştur (2014). Doktora derecesini Sakarya Üniversitesi Sosyal Bilimler Enstitüsü Turizm İşletmeciliği Ana Bilim Dalı'ndan almıştır (2017). Halen Kastamonu Üniversitesi Turizm Fakültesi'ndeki öğretim üyeliği görevini sürdüren Pamukçu, çok sayıda uluslararası ve ulusal nitelikli araştırmayı (makale, bildiri, kitap bölümü, gazete ve dergilerde köşe yazısı vb.) alanyazına kazandırmıştır.

\section{Canan TANRISEVER}

Başkent Üniversitesi Ticari Bilimler Fakültesi Turizm ve Rehberlik Bölümü'nden burslu olarak mezun oldu (2005). Yüksek lisans derecesini Ankara Üniversitesi Peyzaj Mimarlığı Dalı́ndan (2010), doktora derecesini de aynı üniversiteden aldı (2013). University of South Carolina'da hem doktora sonrası araştırmacı hem de eş zamanlı öğretim üyesi olarak hizmet verdi. Kırktan fazla ülkede kongre ve organizasyonlara katılıp ders verdi. İstanbul Aydın Üniversitesi'nde başlayan akademik hayatı, sonrasında Bilkent Üniversitesi'nde devam etmiştir. 1996 yılında Çırağan Sarayı'nda başlayan mesleki kariyeri ise Holiday Inn Crown Plaza, THY, Esmeralda Turizm, ETS, Dedeman, Elit Palace Boutique Hotel ve Karacan Dershanelerinde akademiye katılmadan önce devam etmiştir. Halen Kastamonu Üniversitesi Turizm Fakültesi'nde Turizm Rehberliği Bölüm Başkanı olarak görev yapmaktadır. Temel çalışma alanları, turist rehberliği, kültür rotaları, kültürel miras ve turizm coğrafyasıdır. 